First Peoples Child \& Family Review

An Interdisciplinary Journal Honouring the Voices, Perspectives, and Knowledges of

First Peoples through Research, Critical Analyses, Stories, Standpoints and Media

Reviews

\title{
Voice of an Elder: Zhaawonde - Dawn of a New Day
}

\section{Gordon Shawanda and Cynthia Wesley-Esquimaux}

Volume 5, Number 1, 2010

URI: https://id.erudit.org/iderudit/1069059ar

DOI: https://doi.org/10.7202/1069059ar

See table of contents

\section{Publisher(s)}

First Nations Child and Family Caring Society of Canada

ISSN

1708-489X (print)

2293-6610 (digital)

Explore this journal

Cite this article

Shawanda, G. \& Wesley-Esquimaux, C. (2010). Voice of an Elder: Zhaawonde Dawn of a New Day. First Peoples Child \& Family Review, 5(1), 22-39.

https://doi.org/10.7202/1069059ar

\section{Article abstract}

This paper evolved, maybe 'was birthed' is an even better term given the circumstances, out of an engagement process that brought Gordon Shawanda and several university students together over an academic year. Gordon was invited to attend my Aboriginal Spirituality class at the University of Toronto in September 2009. He liked being there so much that he came each week, sitting through lectures, reading the materials, and participating with unerring grace in the many discussions over the entire year. We were all touched by his presence, his quiet dignity, and his deep interest in our academic learning and sharing experience. Gordon embodies what modern education is trying to get right, the bringing together of theory and practice, and the unveiling of the kind of humanity that can bring Indigenous Knowledge alive for all young people everywhere. Gordon was inspired by their enthusiastic receiving of his words to write down his story. This paper is his first real attempt to express the pain and healing he has experienced over his adulthood. I am honoured and humbled to (gently) edit this work for publication. This is a story that comes directly from the heart and soul of one man, but is the lived experience of many of our people who attended Indian Residential Schools in Canada. It is organized into four parts.
This document is protected by copyright law. Use of the services of Érudit (including reproduction) is subject to its terms and conditions, which can be viewed online.

https://apropos.erudit.org/en/users/policy-on-use/ 


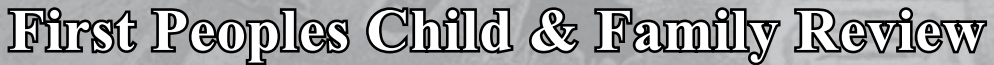

An Interdisciplinary Journal Honoring the Voices, Perspectives and Knowledges of First Peoples through Research, Critical Analyses, Stories, Standpoints and Media Reviews

Volume 5, Number 1, 2010, p. 22-39

\section{Voice of an Elder: Zhaawonde - Dawn of a New Day}

\author{
Gordon Shawanda ${ }^{a}$ \\ edited by Cynthia Wesley-Esquimaux, Ph.D.
}

\begin{abstract}
a Zhaawonde = Shawanda (Dawn of a New Day). My great Grandfather, Zhaawonde was a Potawatomie from Northern Minnesota, USA. It was in the mid-1830's that United States Government agents forced the Potawatomie and the neighboring tribes to leave their lands in what is now known as the Americas. My great Grandfather stayed with other warriors and moved into Canada.

The Potawatomie people and my grandfather's family traveled a great distance and a good number arrived in Mnidoo Mnissing (Manitoulin Island) where they would live free with the Odawa and Ojibwe and help form a nation known as the 'People of the Three Fires', in modern times this nation is identified as the 'Three Fires Confederacy'.

My great Grandfather's name was Zhaawonde, (Shawanda) meaning 'dawn of a new day'. The name came from and old story told and retold that Darkness and Light were two warriors who kept arguing. They chased each other around the world until Dawn came between them, and broke them apart in order to begin a peaceful day. In Potawatomie language, Zhaawonde (Shawanda) is the encouraging colors we see in the break of dawn and the good feelings that a fresh start brings at the Dawn of a New Day.
\end{abstract}

\section{Forward}

I believe that people cross our paths to bring us important messages. The further backward you can look the further forward you can see. This story is about finding out who I am, why I am the way I am. It's about me looking at my experiences as a part of my healing process, and this story acknowledges my greater understanding of the issues facing Aboriginal People today. I was influenced by my upbringing, without it, my story would not exist, so this book is not about attacking my parents, if anything it is about healing a badly broken relationship.

\section{What I Remember...}

Quaan Jaa Lake's strange calm before the storm does exist. So do Aliens. To be creative is to solve a problem. If one does

Questions or correspondence concerning this article may be addressed to:

cynthia.wesley@gmail.com

\begin{abstract}
This paper evolved, maybe 'was birthed' is an even better term given the circumstances, out of an engagement process that brought Gordon Shawanda and several university students together over an academic year. Gordon was invited to attend my Aboriginal Spirituality class at the University of Toronto in September 2009. He liked being there so much that he came each week, sitting through lectures, reading the materials, and participating with unerring grace in the many discussions over the entire year. We were all touched by his presence, his quiet dignity, and his deep interest in our academic learning and sharing experience. Gordon embodies what modern education is trying to get right, the bringing together of theory and practice, and the unveiling of the kind of humanity that can bring Indigenous Knowledge alive for all young people everywhere. Gordon was inspired by their enthusiastic receiving of his words to write down his story. This paper is his first real attempt to express the pain and healing he has experienced over his adulthood. I am honoured and humbled to (gently) edit this work for publication. This is a story that comes directly from the heart and soul of one man, but is the lived experience of many of our people who attended Indian Residential Schools in Canada.It is organized into four parts.
\end{abstract}

Cynthia Wesley-Esquimaux

not have a problem, there would be no motivation. Let's find this out.

I was only eleven when this all happen, so over 50 years have happened in between, and yet my memory is as clear as this day. My brother, Eugene, was going on thirteen. We harnessed our workhorses one morning in early July for a trip to Quaan Jaa Lake with our Dad. The rubber tired wagon was loaded the day before, with hay, camping essentials, and provisions to last us for a month, and, like a treasure of great value a 303 British rife was tucked away orderly in the hay wagon as well. My father having served in the armed forces in Europe was an authority figure who was a difficult man to live with; he ruled with an iron hand. My mother was in the hospital sick from aggravated exhaustion. As had often happened before, 
alcohol had taken control of my father; alcohol was his friend as well as his enemy. Now, we were preparing for a dreaded journey and a month long stay with our father at Quaan Jaa Lake.

Quaan Jaa Lake is a remote area 30 miles into the wilderness from where we lived at Murray Hill in Wikwemikong. The Odawa Nation had started things here in the backwoods centuries ago. It was once a place where councils, ceremonies and celebrations were held, but now they had been cast aside. In the past, I had heard mysterious and puzzling stories about Quaan Jaa Lake. The name Quaan Jaa referred to a being that was often referred to as part human and part serpent. Some referred to the 'living thing' as an all seeing, all knowing wide-eyed protector who observed everything that went on in the setting. Today, remnants of the earlier encampments still remain if one was to look carefully.

I had been down these winding trails before with my mother and her neighborhood friend Stella, when my Father and Stella's husband, Vincent, were in Chapleau Lumber Camp about 500 miles North West from us. In our outings, my older brother, Francis, was the lead-hand, leading the way with the neighboring kids, Ronnie and his brother Jimmy Joe Wakegijig, William and Mary Agnes Manitowabi, my younger sister Roselinda, and Eugene and I. For us, camping at the lake for the weekend, swimming, fishing, cooking, roasting hot dogs in the campfire was always exciting.

It was in the mid 1950s that my father built a cedar log cabin facing Quaan Jaa Lake. A barn was built for the horses for their comfort, which was simply set; a dirt floor was exceptional for the horses, because it was easier on their feet. My Uncles, George and Wilfred, often came from Michigan during the summer to spend their leisure time fishing in the lake and they returned to the same site year after year. My Dad and my Uncles grew up in Dwe ganing or South Bay a short distance from Quaan Jaa Lake.

Strangely, this particular summer morning, it was not the same. I felt this trip was not for me. More importantly, I wanted to stay home and be with my mother. Regrettably, Eugene and I were home only for the summer holidays, and we were required to return to the residential school in the fall. Now, we must help our father cut pulpwood for the summer. In those days money was essential to survive, and for many, cutting timber was the answer. When we arrived at the log cabin the terrible loneliness and fear was upon me again, the same lonely feeling that I felt when I was first taken to the Indian Residential School (IRS). In my experience, the need for caring, kindness and gentleness was once again missing. I never realized then how much a child's development and growth needs the care and closeness of a mother. Obviously, my Mother was missing in my youthful life, but already and continuously, I kept my feelings to myself as life went on.

My father worked about a mile away from the cabin, the only time we saw him was in the morning and in the evening. In the late afternoon he would come after the horses at the barn and haul his pulpwood to the campsite. Our job was to peel the 4 -foot pulp, which he already had cut. What can eleven year old do with an axe I thought? But I soon learned watching my brother. I learned while living in the woods that a poplar tree carries more water than any other tree; therefore it was easy to peel. The horses, Barney and Sandy were tough, and they always had that one more burst of speed, energy and power. My father was a top horseman and he always brought out the best in them. He made sure the horses were always fed and groomed, hooves cleaned, with proper shoes and he would always say, "Horse grooming is essential to good health as well as appearance."

Usually after supper my father and my brother would go out again for an hour or so to peel the bark from the poplar trees already cut. I tried to help as much as I could, but I always seemed to spend more time bonding with nature. Day after day in the late afternoon I played in the mud puddles by the muddy wagon road, catching frogs, baby turtles and watching tadpoles swim. Some days my contribution would be to catch fish and pick raspberries for an appetizing meal. So I wouldn't be bored to death, my father gave me a steady chore, to brush out

\section{Living Memory:}

My memory takes me back to when I was 5 years old. I remember it was a few days before Christmas on a beautiful afternoon. The sparkling snow was falling gently. My brother, Eugene, and I were both thrilled to be going out with our father to look for a Christmas tree. Our two horses, Barney and Sandy, were pulling the sleigh and it was running slowly. The decorative sleigh bells were jingling on the black harnesses that the horses wore and as I watched closely down at their horseshoes, they would kick snow back at my face. It looked hilarious and it made me laugh continuously. As we drove onward through the field into the deep woods, I could see the beautiful glittering snow covering the evergreen trees and the winding rabbit trails leading to every direction. This nature scene was an awesome one, a scene that no person could ever forget. That night, as Eugene and I watched excitedly, our mother decorated the glittering evergreen tree and we listened to the Christmas songs playing on the old battery-radio. It was one of the happy times we spent together and is a memory that I will never forget. Today, I ask myself, what made the world so different? Winter must be cold without these warm memories. G.Zhaawonde 


\section{Zhaawonde - Dawn of a New Day}

\section{Definitions}

Aboriginal people - includes Métis, Inuit, and First Nations, regardless of where they live in Canada, regardless of whether they are registered under the Indian Act of Canada.

Assimilation - a dominant group effectively impose its culture on other groups in ways for them to become virtually indistinguishable from the dominant culture, acculturation.

Disability - describes what disables, such as an illness or being deprived of normal strength or power.

Disease - Any harmful condition. Poverty is a disease to society. In the scientific paradigm of modern medicine, diseases are abnormalities in the structure and function of body organs and systems.

Indian - was wrongfully used by the explorers

I R S - Indian Residential School

Legacy of Physical and Sexual Abuse in Residential Schools - often referred to as simply (Legacy) meaning the on-going direct and indirect effects of physical and sexual abuse at residential schools. The legacy includes the effects on survivors, their families, descendents and communities (including communities of interest). These effects may include, and are not limited to, family violence, drug alcohol and substance, physical and sexual abuse, loss of parenting skills and self-destructive behavior.

Loneliness - "solitude split off from the community is no longer a rich and fulfilling experience in inwardness; now it becomes loneliness, a terrible isolation."

Rain Dance - an ancient ceremony of sacrifice, consist of fasting, drumming, singing, dancing, piercing and feasting.

Residential Schools - The Residential School System in Canada attended by Aboriginal students, including industrial schools, boarding schools, homes for students, hostels, billets, Religious based residential schools, residential schools with majority of day students or a combination of any of the above.

\section{Standing people - trees}

Survivor - an aboriginal person who attended and survived the residential school system.

What is Trauma? - Increasingly, psychological trauma is understood as an affliction of the powerless. During the traumatic event, the victim is made completely helpless by an outside force. When this force is one of nature, it's called natural disaster, when it is human to human, it is called an atrocity. Traumatic events cause people to lose a sense of control, connection and meaning.

Turtle Island - In North America the term proudly used by Native People. The belief that the world they knew rested on the back of a giant Mshiikenh (turtle).

\section{Spirit Names Are Ancient, and These Names Are The Names Of Our Ancestors}

When the Europeans first arrived they couldn't pronounce our names, so we were given English names. Some people kept their names and recently some went back to their original name. The names written down here have other meanings. There are 3 dialects spoken in Wikwemikong.

Alec-koonh - alec, alek, alexander

Akwesasne - where the partridge drum, St. Regis

Anishinaabe - Ojibwe, the language they speak, identifying a native.

Anishinaabemowin - Ojibwe language, the native's language

Bebamikawe - family name in Wikwemikong

Bezhniik - Virginia

Bkejwanong - where the waters divide, Walpole Island

Byencesag - little people

Boodwe waadmii - Potawatomi Nation, Firekeeper.

Chi-mama/Nookmis - grandmother

Cochichiing - one of the Reserves in Fort Francis
Dawaganing/dweganing - a place of drumming/ where the elders drum, South Bay

Epnigishmog - one of the Four Grandfathers, of the western direction Epnigishmog - a Spiritual leader Sunset, who brought the Rain Dance back to Mnidoo Mnissing after it was well hidden out west.

Gch-piitendaagok - all sacred things, sacred values.

Giiwednong - one of the Four Grandfathers, of the northern direction Kaboni - a family name in Wikwemikong

Niigan Naazhea - shinning ahead/one who gives light (brilliance) in future Maaniiyanh - Mary Ann

Manitowabi - a sacred sight

Mishibinijima - left behind

Mshiikenh - turtle

Mishoomis - grandfather

Mnaadenmowin - respect

Naakoowaam - distant thunder

Naandwedidaa - healing one another

Neyaashiing - be a point, of land/cape. Cape Smith

Negannigwani - pheasant

Niiwen Mishoomsag - in Ojibwe, the four spiritual grandfathers (guardians) north, east, south, and west, direct/guide us throughout our life.

Odawa/Ottawa - one of the 18 Algonquin nations in North America.

Mnidoo Mnissing (Manitoulin Island) is the homeland of the Odawa, the Ojibwe came afterward, and then the Potawatomi followed. These three groups are known as the People of Three Fires, more recently recognized as the Three Fires Confederacy.

Ojibwe - peacekeepers, members of the Three Fire Nation

Tekemah - a family name in Wikwemikong, a little town outside Manitowaning.

Petawanakwat - in among the clouds

Pwaagan - pipe

Quaan Jaa Lake - a living thing

Shawana - a family name in Wikwemikong

Shawanda - dawn of a new day, Fine Day.

Shigan - bass/fish

Takwadjiwan - tidal wave, Lewis

Waabnong - one of the Four Grandfathers of the eastern direction

Wakegijig - wavering cedar

Wassegijig - bright sky

Webkamigad - beginning of an event

Wikwemikong - Bay of Beavers, pet name Wiky

Zhaawon'de - dawn of a new day/Fine-day. Zhaawonde is the Linguist style of writing I learned at Lakehead University in 1992, while I was doing the Native Language Program. I use the name only when I write a story. I remember one of our Linguist teachers Randy Valentine saying, I still hear an $\mathrm{O}$ sound in there Gordon. It took me 3 years before I could hear an $\mathrm{O}$ sound and use it. An Elder once told me, it's good to have an $\mathrm{O}$ in our name. It is up to the individual to find out that meaning, and I see Jawande written in the very old church newsletters. The name may have been use by the early Jesuits.

Zhaawondens - translated to English ens indicates, noun diminutive meaning minute, smallness, cute, always ends in "ens"

Zhaawnong - one of the Four Grandfathers in the southern directions

Zhoolyea - Julian

Nishin Aasagaabwiitaadying - it is good to support each other.

Miigwech - Thankyou 
the sweat and dust that accumulated in the horse's coats, and gently comb out their manes and tails. This early horse training created special bond in me for a lifetime, a relationship built on trust and respect for the horse, as well as all animal life.

Sunny days came and went. On stormy nights my Dad would say, thunder beings are here for a visit. If you wish, keep your eyes peeled and ears open. As I lay in bed, a short distance away the incredible sound of lightning bolts crashing against the trees made my spine quiver. I'd jump from my wooden bunk bed and stand by the lone window in the cabin and watch the flashes from the lighting as they shone on 6-foot waves in Quaan Jaa Lake. I enjoyed watching the flashy thundering storms and listening to the whistling sound of blowing wind. The light was so bright it made my eyes blink and sometimes for a split second I could see the white seagulls flying high in a twirl as if they were caught in the raging storm. Completely lost in thought, it was like magic, a fantastic sight to see nature at work. Nature is divine and peaceful yet frightening in its power. As the storm finally came to silence the gentle rain hitting the tar paper-roof would eventually put me to sleep.

In the early morning after one rainstorm, curiosity led me to walk in the woods under the sheltering trees where freshly washed leaves were ready to spill their tiny cups of water on me. Mosquitoes hummed and danced around my head ready to bite. A few feet away, I saw a tall pine tree with a split branch, where I heard a sharp crack and a booming sound during the night's heavy storm. There, a huge fallen branch lay dead on the ground and I knew that it would one day be revived with the life power that is in nature, giving food to other living things and would soon be humming with new life. The dampness everywhere was somewhat discouraging, but I understood that the thunderbeings came for a reason. We needed the rainstorm to nourish the earth. When the morning sun came shining down through the leaves of the tall trees, it was the most beautiful place to be in the world, fresh air, green forest, glossy white birch trees with their little red marks, robin singing its cheer up song, and happy glowing different colors of wild flowers adding to the beauty of nature. A few steps away a cold stream slowly tumbled and murmured along and I knelt down for a drink of cold fresh water. I watched and listened to the tiny pebbles as they mumbled words to me. I could see and hear the bubbles, but the forgotten language they spoke to me was long lost in time.

My Chi-mama (grandmother) always told me Anishinaabe (Native people) understood nature, because they were part of nature. They understood Gchigami ( lake-water ) the strange calm before the storm. They understood the Spirit of blowing wind, the talking leaves, and the cry of the wolf. They understood the sky-world, the messenger clouds, and the dances of thunder-beings. Rocks and trees were regarded as sentient beings, sacred in their own right and entitled to great respect from human beings. The brilliancy around me made each day a little brighter, and it was truly a place where one can surely forget his problems. But still, I wanted to be with my mother. There is nothing stronger than a Mother's affection.

One sunny morning around ten o'clock, I took a stroll to take my father some fresh tea. As I arrived he laid down his axe. He said son, let's share this moment with the animals, and let's listen to the silence in the forest. Not noticing the stillness before, it was absolutely amazing to me. There was not a sound in the woods. My father told me, this was around the time of the day that all the forest animals took their break. The whole time I was in the forest I had never understood respect for silence existed amongst those intelligent Creatures.

Moments later, all hell broke loose. Two squirrels were chasing each other up and down the trees, a red headed woodpecker was tapping a tree, and birds were brightly singing their own songs. Suddenly from a swarming hive, a black bear was swatting bees, even the brave shigan (bass) was jumping from the water to telling us Quaan Jaa Lake was ready to give. Not much was ever mentioned about Nature's language, nor was I ever before made aware of the communication going on around me. With a sense of amazement, I felt so great, because even though I may have blamed my father for his behavior, he and I found ways to bond.

That day, I will never forget my father telling me that Eugene and I need not go back to the Residential School. He was home to take care of us and that even though my mother was in the hospital from exhaustion, she would be home when we got there. It was gratifying to know she was in a safe place. When I relayed the message to my brother Eugene, he was overjoyed. This was truly a heartwarming day for us.

My mother was a stay-home mom; a strong woman, she believed there is no greater curse than total idleness. She worked hard on the farm, churned butter, planted and harvested crops, picked wild berries, and treasured her flower garden. My mother was an excellent cook. No one came into her home without a big welcome and no one ever left hungry. In spite of her struggles; with my father serving in the arm forces in Europe, and her children taken away by Indian Agents, she never lost her sense of humor. Her smile showed her kindness and gentleness. One's mother is always a loving mother.

My mother's maternal father, Alec-koonh was well known in the Village of Wikwemikong. He lived in the rural community Neyaashiing (Cape Smith) and he was once a harness racing champion in the County Fare event at the exciting harness tracks of Manitowaning in the mid 40's where he competed against the best. My Grandfather was also a Fortune Teller known for reading tea leaves and he was gladly welcomed 
everywhere for a cup of tea and people would listen in silence to his astounding stories. I would hang out with my Grandpa, and on New Year's Day he would pick me up in his cutter (onehorse sleigh), a two-passenger sleigh used for special outings. We would take a trip towards the Kaboni Road for the New Year greetings and visit his brother David and come back on the long swerving trail known as the Webkamigad road. The New Year greeting was an event that was still popular in the 60s, but has since disappeared. My Grandpa was the last Person to own and ride a one-horse drawn sleigh and buggy in the village of Wikwemikong. I thank my Godparents for naming me after my Grandfather Alec koonh (Alexander), for one to be named after their Mishoomis (Grandfather) was very special.

When ever I heard a loud truck coming towards the cabin I would run to the road where the pulp was stacked in rows. My brother Eugene would already be there, gasping for air. We always knew Frederick Petawanakwat would come by in his big maroon truck to haul our pulp. Fred was fun to be around with and he would often drop off a small bag of marshmallows. It was a big treat for Eugene and me. Roasting marshmallows in the evening campfire was exciting. Frederick frequently spared a few minutes to tell us cheerful tales. One story he told was about the Byence-sag (little people). Should you ever see the little people roam around in the forest, you'll be lucky, for they signify good luck. He said, "The Byencesag lived in water and they are rarely seen. Whenever you feel lonely or depressed go to the lake just before it rains. Cleanse yourself gently with water and when the little raindrops drop, you will hear the little people speak in the ancient language. You may not understand what they are saying. But those little rain spirits will cheer you up." His stories made my brother and me aware of the supernatural.

Frederick would always remind us, keep your head up and remember where you come from. Don't ever run away from the Residential School you will only make things worse for yourself. Fred told us he was also in the IRS. Eugene was always fascinated with 'muscle body builders', like Charles Atlas in the 1950s and Frederick was a big man. He said, Dad told him that Frederick was a powerful man. He once heard a story that Frederick rolled a huge stone aside that had fallen from a cliff, off the middle of the road. There were three workers who were traveling with him and who weren't able to budge the rock. Frederick got out of his truck and told the 3 young men to take a rest. Like a mountain goat, ready to charge he dug a grip with his feet in the ground, and with his bare hands and his powerful physique, he rolled that huge fallen-rock down the steep rugged cliff and the three men stood there watching him with their mouth open in awe.

Eugene and I had watched Frederick load up his truck several times with the curve hook, tossing heavy pulpwood like they were sticks. Fred was in great physical condition with good coordination. In 1960, my brother and I were saddened to hear about Frederick's accidental drowning. Fred was our dear friend, a happy go-lucky caring and a powerful young man whom we admired exceptionally. We greatly appreciated his friendship in the short time in which we knew him and we learned a great deal from him.

\section{Aliens Invade Quaan Jaa Lake}

One day I was playing by the lake when an old man came by. "What is your name?" I asked. "My name is Mshiikenh (turtle)," he replied. He sat down on a stump by the low flame campfire facing the lake. I offered him tea. He helped himself gently. I remember your Grandfather well, he said. "His name was Naakoowaam (distant thunder) Joseph Zhaawonde. He was a constable in this area, South Bay, for many years; he worked with the Mounties," he said. My Grandfather died 1946, 4 months before I was born, I explained to him.

I could hear Mshiikenh sipping hot tea from the old tin cup as I sat next to him. There was something about this Elder that made me feel safe and cozy and I soon found out why. "I have something to tell," he said. The story he told me I can now tell. It was about the terrifying Serpent they called "Quaan Jaa" who once appeared in a time of need. "The Spirit of the lake is alive," he proceeded to tell me.

Many moons ago strange, menacing, 'monsters' resembling people came to this land. An extremely large spaceship shaped like a mushroom with lengthy spider legs and rays flashing like northern lights landed in Quaan Jaa Lake. The mysterious figures with hairless heads had a mechanism that helped them perform human tasks and made them easily pass for human beings. They came from a place beyond man's reach. They came with violence and a scheme to kill, take, and to destroy all the fire-breathing animals and abduct human beings. Flames came out of their weapons. They scorched the land with fire and the village was burned to the ground. The people were scared to death. They ran for their lives. Six children were abducted and one of our extraordinary leaders named Niigan Naazhea (ahead of the light) valiantly fought them off, but was also taken into the ship with the children. The space-ship eventually lifted-off, and the Alien Invaders were not to appear again for half a century.

In the deadness and quiet in the moments following the lift-off a masculine brave named Negannigwani (pheasant) became the new leader of Quaan Jaa Lake. Negaanigwani is from the feathered clan, a symbol of leader-ship. He was instructed that he must travel to Wikwemikong (the bay of beavers) nestled in the valley with a cast of towering hills filled with resources. He must inform the auspicious leader Tekemah (where ability is) about the horrifying incident that took 
place at Quaan Jaa Lake. In those days Wikwemikong was the meeting place (capitol) of Mnidoo Mnissing (Manitoulin Island). To Native people the Spirit Wikwemikong is a skillful builder' who will bring new directions and new life back to Quaan Jaa Lake.

After the Negannigwani and Tekemah meeting they spoke to the people. They had come to believe that the Aliens intentions were to come to earth to live among them and steal the Gchi pittendaagok (sacred values). To wipe out their way of life and to break all the Indigenous people on planet earth and slowly destroy their spirit mind, so that they could become like them. The Aboriginal people only wanted to live in peace and harmony with nature. They respected and communicated with that which the Great Spirit created, but the hairless creatures that were very much Alien to them, because they were programmed by machines, could not be ignored.

Half a century passed before the aliens returned to Quaan Jaa Lake. The People were puzzled to see the man they thought was dead. Even more mysterious, Niigan Naazhea had never aged. Sadly, the six children taken never returned home. They stayed at the Meteor where they had been taken and were held there by the power of the harmonious rock, and they remained deeply attached. The never-ending machines and the Aliens' plan had caused the children to forget that they had a home to return to. Yet, the Alien magic failed to work on Niigan Naazhea who was a star, a leading light in a living form, the gifted spirit of the future generation. In his short stay, Niigan Naazhea informed the people what was going to happen on the planet. He said many Natives were already beyond the bright lights and had been secretively abducted years before him. He told his people when the age of technology arrives welcome it as a value for everything comes as a reason. When you do so, you disarm it of any power over you. Some day machines will take us to distant places. The Aliens living standards will be passed on to us gradually. The Native people noticed their former leader, Niigan Naazhea, was talking out of the ordinary and he even walked rigid, except that his shining long black hair was still intact.

Negannigwani who became the chief of Quaan Jaa Lake, was a Pwaagan (pipe-carrier) and was also a seer known to tap into the universal creative force that underlines nature; the journey of souls. He was keeper of the days, responsible for naming the days, and observing and recording events in the heavens. Negannigwani was also an extraordinary leader from all indications. There are still many stories and like the Spider web, in those days the Native people where closely connected with the sky-world.

Then another dreadful day came. The Aliens kidnapped another six children and re-captured Niigan Naazhea. This was the last time Niigan Naazhea and any of the many children taken where seen on the planet earth. A decade later, the aliens once more returned to Quaan Jaa Lake with no trace of the other people that had been abducted in the years before. The Aliens were now unable to find the fire-breathing animals they had hunted for thousands of years. As they were getting prepared to departure, they forced more Native people to leave. Restlessly, waiting out of their reach was the incredible Tekemah; he was on hand to witness the abduction. Connected like the Spider-web, he was able to evoke the last of the Fire-Breathers, the monstrous serpent Quaan Jaa, to make her presence known. Danger was near at hand, and preceded with a gigantic wave, moved by a powerful energy force, the Monstrous Serpent appeared, casting a giant shadow on the startled Alien invaders.

The people scrambled and made their escape as the Giant Serpent made an attack on the space ship blowing fire and causing an explosion from which there was no escape, and killing all the intruders. Again a great terror filled the homes of Quaan Jaa Lake. Many people were traumatized, but the few who were left were protected by the unseen force of 'Quaan Jaa the Serpent.' She had emerged as a tidal wave and swept the frightened people across the lake to where a huge rock stands at peace. The hairless Aliens were never seen again in Quaan Jaa Lake.

On calm evenings, night Chants and the sacred Drum were often heard coming from the naked rock across the bay. Tekemah the gifted mystic knew from various findings that Quaan Jaa never showed her face in full daylight. So the Odawa's chanted and drummed on calm evenings. Sneaking a look into the night skies, Tekamah could see far-off Nigan Naazhea blinking in communication. Tekamah discovered through Quaan Jaa Lake's mirror image, that the aliens had long established a presence on earth and they had gathered information on us for thousands of years. Tekemah informed his people; welcome the hairless, they are the far-off, far-out Aliens made of technology. Don't be afraid of them, because we are one with the earth. After they move on, we will still be here.

Unexpectedly, Mshiikenh asked me, are you OK son? Still in a daze, I answered I'm OK, just a little shaken by your story. The old man smiled. I gladly offered Mshiikenh another cup of Naadwewashk (herbal tea). Mshiikenh explained, "our ancestors were drumming in this area for centuries, they call this place Dwe'ganing (where the Elders drum), now known as South Bay. Quaan Jaa Lake is a sacred space, powered by the sun ahead of all lights. People came to this lake years ago to meditate. It's a special place," he said.

My brother and I swam quite often in Quaan Jaa Lake, the water was dark and cold, but we liked it that way because it 
made us tough. We swam with the water snakes; every time we saw the little serpents we greeted them with stones, not knowing their purpose in life and why they came around. I was thankful Mshiikenh came by frequently, we learned a lot from that Elder. He saw what we were doing and he asked, "Why are you killing the snakes? Would you greet me with stones? The snakes know you are here and they come to visit." "They're our relations," he said. "The snake has good medicine, and it has both good and bad power. A good doctoring power used for seeing and healing. Turtle is not so different, as it supports the earth like the snake. I'm from the Turtle clan that's how I know and that's why I'm telling you this. Next time you see water snakes, talk Anishinaabe (native) to them and they will hear you," he said. From then on we let them alone. We learned to appreciate why they are there.

Mshiikenh was a wise man and he would tell us how everything in nature is "our relations" the rocks, water, trees, animals, and all that is in the sky-world. Seeing the world as the Great Mystery was encouraging. One evening while playing and hollering around, my brother Eugene heard voices in a distance. Now we realized the enormous rock across the Lake was full of life. Soon my brother and I worked out our vocal cords and hollered out to the talking stone across the lake, and the beautiful ancient hollow sound of the echo would return to us. We had discovered another fun-loving entertaining activity in the beautiful surroundings of Quaan Jaa Lake.

I began watching the changes of Quaan Jaa Lake more carefully, the beautiful sunrises, the gorgeous sunsets, the huge waves, and the change in color of the standing people. Everything seemed to be alive and gave meaning to our existence. All this was soon forgotten as I went on into different levels of awareness and experience. But I always kept in mind Mshiikenh's fascinating story because I knew there was more to it than just another legend.

On our last day at the cabin, my father came home from hunting with a deer slung on his back. Before sundown another hunter, Baagizhenh (Ambrose Kitchicake), whom my father had known for years, stopped to visit. After a while the two of them were full of activity; cooking, packing and storytelling. Our visitor was my mother's relation, a very helpful man, and enjoyable storyteller. As I fell asleep that night, I could hear their low voices by the crackling fire until the wee hours of the morning. In the morning the delightful sound of birds singing awoke me. I was ready, anxious, and excited to leave.

After breakfast my Father, Gene and I hitched the horses to the rubber tired wagon. We left the cooking utensils behind at the cabin for others to use. As we rode away from the deep forest, I was surprised at my mixed feelings. I felt a keen anticipation to see my mother yet I felt a little sad to be leaving our log cabin and the fantastic surroundings of Quaan
Jaa Lake. However, the experiences that summer gave me a little of the wild that I would come back to sustain me when I needed that comfort, and my exploring gave me unforgettable memories of my boyhood days in Quaan Jaa Lake.

\section{End of Part One}

\section{The Indian Residential School (IRS)}

Promoting awareness and public education about IRS System and its impacts on the Human Dignity of Former Students.

In the Second World War my father volunteered and joined the Canadian Armed forces in Europe. There he was accepted as a "man" and he ate at restaurants and drank in taverns with other men, unlike in Canada where he was prohibited from making those choices. Upon returning home there was no opportunity to grieve their losses or heal their shock and trauma. Returning Native soldiers were still restricted in drinking on the Indian Reserves, and they were not allowed to vote, buy liquor or drink in town hotels, or work outside of the Reserve.

A Native soldier who risked his life to defend Canada gave the highest possible gift he could lose; his life. The Native soldier in Canada was forced to be a farmer. Native people were subjected to punishment for not enfranchising into mainstream society. Then my father heard that laborers were needed to make a passageway for Hydro Power Lines in the backwoods of Northern Michigan USA, he left Canada. He took his selfish pride as a man and left. As a result, I ended up in the Indian Residential School and suffered under the hands of the Jesuit Strap.

I don't remember the very first time I left home for St. Charles Garnier Indian Residential School. My older brother Francis remembered, and I apparently put up quite a big fight, kicking, crying, and pleading not to go. I was only 6 years old, while my brothers Eugene and Francis were 7 and 9. I distinctly remember arriving and being fixed up with school clothing with my new name ' 67 ' inscribed on them. I remember being led to the field to join the game of soccer, where I asked myself, "What is soccer?" I especially remember that I was scared watching the kids play. I had never seen any kids as rough as the ones I was to play with and against, but I soon became like them rough, tough, and hard to break. That was the effect of long-term confinement at this school. At bed time I would cry myself to sleep thinking that loneliness would forever surround me. My first trauma of being totally separated from my mother, and sent to this school, hit me severely.

Sundays were visiting days for the boys. The girls came over from St. Joseph School across the street to visit their 
brothers. The boys with no sisters had no visits and were chased outside into the freezing cold, but some of us would sneak into the barn to keep warm. The clothing provided was inadequate for the cold weather and my hard leather shoes were always too tight and my feet were often sore and cold. For me, longing for my family were the hardest times for me, and the loneliness hurt me more than the malformed toes I still have from the ill fitting shoes I was forced to wear in those early years.

I remember that in the dormitory all of the students slept in bunk beds. I once slept on top of the bunk, but because of my bedwetting I was transferred to a bottom bunk. I may have been 7 years old when one night after the lights went out an older student who slept on the bottom bunk next to me threatened me. He said he would beat me up if I didn't perform a sexual act on him. I never told this to anyone and this has always bothered me. I was too afraid to report this incident. Children who tried to report sexual abuse or any kind of abuse were strapped for lying.

I learned later that when a child is sexually abused there is so much that is denied. The child experiences trauma and when trauma takes place in a child's life, they stop growing. The child does not grow like other children. As the child ages, they may become abusive themselves. There is a lot of fear, and anger replaces the fear.

Another instance of sexual abuse was when I had chicken pox or measles (not sure which), I was in the infirmary, and was kept in a dark room for five days. As I lay in the bed the prefect Brother Laflamme would come and check the red spots on my body. To the best I can recollect he abused me three times while I was sick in bed. His idea of nurturing was sexual touching. In the winter evenings it was mandatory for everyone to go to the infirmary on the third floor for a tablespoon of cough medicine, which for us was a dose of cod liver oil. We would march in single file ten at a time. There was always a scary feeling inside me when I had to see Brother Laflamme. He was the physician known as the magician who played with generators. He would give us a shock treatment on our visits. He had us line up and clutch hands and then he'd turn on the electrical gadget, and the volts would go through everyone's arm and the person at the end of the line would get the biggest jolt. It was another one of his warped and sadistic ways of having sick fun at the children's expense.

Emotional abuse came in the form of constant ridicule. I had bad kidneys and wet the bed. All the "piskers and piss bombers" as we were called were subjected to constant abuse and ridicule. Every Saturday morning I was ordered to line up with other bedwetters and we had to drag our wet mattress to the barn to change the straw. Our weekly ritual was to walk between a gauntlet of jeering boys and laughing priest dragging our mattresses. No one will ever know the real extent of pain, blame, and shame we each experienced inside of ourselves for bedwetting. We couldn't help the physical condition. Everyone slept on a mattress, but I and the other boys with the same problem were required to sleep on a straw mattress all during our stay at the school.

Another source of abuse came while playing ball or marbles. I would hear the priest yell "Scramble." I would drop what ever I was doing and run to the game of scramble. Father Brennan took sadistic pleasure in tossed jellybeans on the ground like he was feeding hungry chickens. I became a regular in the game of scramble by being rough and ready. Charging, bumping heads, and scraping knees, bruised black and blue and crying just to get a jellybean or two. The game of scramble was always cruel, and aggression teaches violent behavior. But I was hungry all the time, because there was never enough food, and many times I would have to hide lard under the table to use the next day for buttering bread. I would be lucky if it was still there the following day. I know others were hungry too.

There were many sports played in the institution. One sport where one had to shape up and be alone was boxing. In this annoying game, we were blind folded with potatoes sacks, not seeing where your opponent is and not knowing when the next damaging blow to the head is going to knock you silly or angry was very difficult. Many times I was put in the ring and many times I was hurt. This activity looked amusing to the children, and I am sure I gave them the impression of looking like a clown in my confusion. To the priests I think it was just another one of their sadistic misbehaviors. Their expectation of toughness was taken seriously, and they obviously believed that pain and punishments was the answer to making a kid wake up and behave. From this "sport" I went on to learn to hit first and ask questions afterwards. I was also minus three knuckles. Boxing blindfold in potatoes sacks as sport came to an end when one kid was seriously injured.

Hockey is Canada's game and playing hockey was mandatory at the IRS. One Saturday morning I was rushing to participate in the hockey game. The ice surface was divided into four sections, and group teams played in the morning immediately after breakfast. I may have been nine years old and I liked playing hockey. That particular morning I didn't have time to take out the straw mattress to replace the straw. For my punishment, I had to clean toilet bowls and urinals for a week. Lavatory duty was used as punishment or as a means of force labor. I worked in the cold latrine for a whole week for not taking out my wet mattress.

Alfie Morrison was a kid from Cochichiing (Fort Francis) Reserve. It was Alfie's hockey skill that attracted the attention of all the native boys and girls at the Indian Residential School. He was our Hockey star in the mid 1950s. Other great players came before and after him, and one who became well known on my 
home team of Wikwemikong, was Max Simon. Constantly, we were warned to concentrate and keep our eyes on the game, not on the girls, otherwise, we would be punished. The cheering and excitement was no doubt tempered by the disturbing feeling of the possibility of getting strapped. Looking at the girls meant you were doing something morally wrong. Yet, at times we were allowed to public skate with the girls in the arena at the IRS it was terribly confusing. It was a confusion that never quite went away in my life.

There were many great players who played at the Indian Residential School institutions in Canada, and later for their home communities. Had they been given a decent chance, they would have easily made the big leagues. Max Simon went on to play for the All Native team called the Wikwemikong Flyers, winning three Championships against the five NonNative teams on Manitoulin Island, eventually retiring in Wawa, Ontario. Alfie Morrison and the boys who once teamed up at the Spanish IRS got together and joined a league in the Windy City (Chicago) where they all worked in the early 1960s.

They were called the Elden Blades. They were truly a force to be reckoned with and these young men also captured three Championships against the Non-Native teams in Chicago. The Residential School was a combination of survival and battlefield. The boys worked hard and played hard; win or lose. The Priest may have been a great influence simply because they were superior at coaching and yelling and issuing punishment if you didn't heed their words.

One afternoon, I may have been nine years old, we were playing in the schoolyard near the barn area when we heard as lot of noisy gobble sounds and saw that somehow the long neck birds had got away. A few of us children ran after the reddish-headed turkeys, trying to help hurl them back over the fence. I must have looked like a thief, but really I was just having a difficult time trying to toss the flapping bird over the wired fence, when unexpectedly I felt my left ear burning. I was being slapped upside the head by a farm worker, and the blow to the left side of my ear knocked me to the ground. It was another of the sadistic brothers, Voisin. Blood came pouring out of my left ear and he sent me to the infirmary. When the other sadistic brother Laflamme, asked what happened and when I explained what had happened, he stuffed cotton balls in my ear and send me back to play as if nothing happened. Today, I still have problem hearing.

When a dozen of us received our First Communion in the Roman Catholic institution we were given special treatment; a day off from school, and we were given three special meals in a special room. We were fed highly pleasing meals; the fineness of tasty treats that I had never seen on the table in our dinning room in the residential school. The older boys that worked in the kitchen revealed that was how the Jesuits ate everyday, but we were denied necessities and fed days old food, spoiled bone soup, leftover from the scrap bones of pork and beef, green corn meal, smelly mush, and lard for buttering bread. In this school, the priest ate divinely and drank wine, while 'us' kids were starving.

One evening while we were having supper, they brought Joe Ratt down stairs from the main office on second floor. Joe had run away from school and had been caught. When they brought Joe downstairs for supper his head was completely shaved to the skin. He glanced around the tables and saw that everyone was looking at him in various degrees of shock. One student nervously laughed and a fight erupted. Next thing I saw was Prefect Father Orr and Joe Ratt under the table fighting, struggling, and kicking. It was terrifying, watching the horrifying incident.

Spiritual abuse was a hurtful reality on a daily basis. We were called pagan because nature was our spiritual way of life. It defined our culture and spiritual ceremonies. By tradition the medicine men and women on our homes opened their sacred bundles as soon as the first echoes of thunder-spirits were heard. Spring was welcomed because the rain nourished all sacred living things. Each bud on a tree was regarded a spirit opening out to our Environmental Spirituality. The wolf is our brother we shared the forest with the animals. We asked ourselves why can't we be just natural like the birds and sing our own songs? The Residential Schools began rooting out traditional values and beliefs in our heads, and planting Christianity and its values and ways in their place.

Confessions took place Friday evenings week after week. Confession was not easy, and sometimes very confusing. If I ever said, "I have no sins I didn't do anything bad." I was called a liar and told it was a sin. The priests said, "You have to be a sinner." I was instructed to say, "Bless me father for I have sinned." After saying this, I would just lie and say, "I did this, I did that, I stole this, I stole that." It seemed that lying was the only way to satisfy the Holy Father.

I was also strapped for inquisitiveness. Sunday was church day. When we walked down the Isle in church we were strictly informed that we were not allowed to turn our heads to the right where the girls sat. Some boys were looking and trying to spot their sisters, and for others it is a natural habit to observe. Natural curiosity about the opposite sex was discouraged. One was made to feel ashamed for even having such curiosities.

Showers made me feel withdrawn and inferior. While taking a shower Father Brennan would stand in front of the door watching and staring. His constant stare reminded me of a hawk ready to pounce. He was a man who hid his sexual perversions and sadistic tendencies in the covering of holiness. He would say you stink because you piss in bed. The pee smell 
was strong from the steam shower as it washed off my body in front of other children, always leaving me feeling shame. Scarred from that childhood experience, to this day I don't take showers. I never took showers at the steel plant where I worked for three years and still don't take showers where I work out at the fitness club with other men. I carry the deep feeling that my body was something to be hidden and to be ashamed of.

Now and then Saturdays were designated as days for long walks. Occasionally a senior 'native guide' would be in charge, which always made it more pleasurable. The one in charge would ask us 'where do you want to go today? Us kids would holler out, "Smith Lake." There was an attractive lake close by Saint Charles Garnier Residential School, but Smith Lake was our favorite place. Spanish town was about a mile and a half from the Residential school and Smith Lake was about three miles. We would all march through the little town slowly two by two, all staring at the candy store as we passed by. As we slowly marched onward we would stare at the greyhound station wishing we could get on a bus, and wondering who was getting off. When we finally came to Smith Lake everyone would be excited knowing what we were after. When we arrived at the hidden lake it was like little prisoners getting released from prison. Everybody scattered, yet most kids were drawn like a magnet directly to the landfill site lake, which was close by. In spite of the garbage at the nearby dump, nature heals. Smith Lake was still a loving place to choose; we were able to run free and feel happy again. It was a place where I first learned how to swim, and it was a peaceful place for swimming. It had cool clear water, fresh air, the fresh smell of pine trees, birds singing their own songs. Sometimes, in an amazing stroke of luck blueberries would be growing on the high rocks above the landfill and 'us' kids would be in our glory. About an hour after the initial scatter, everyone would be running around with slingshots. The black tire tubes at the dump served their purpose. For ammunition, bits of pinecones would be flying in every direction; older kids would secretly roast rabbits, and others would hunt partridge. It was fun while it lasted. This last time would prove to be the end of Smith Lake for all of us. Come Monday morning a barrel full of slingshots was confiscated by the black robe priest, and we knew that some title-tattle had leaked out.

We took advantage of being alone, to break free of the rules forced upon us. We felt pride in being Native, rebuilding our minds and spirits. That place was my favorite place, the freedom I felt there; my life so full of love. As I'm writing this section, I am smiling, yet I'm teary-eyed with a lump in my throat looking back and imagining us little children scampering about so happy, and yet so lost.

On several occasions big bullies beat me when the prefects weren't watching. My father wasn't there to protect me. My mother wasn't there to comfort me when I cried. I needed my parents. It made me feel angry and confused knowing my parents could not help me and wondering where they were, not knowing they had no say in the matter for me being where I should not have been. The only people I was acquainted with were the men in black robes who had no experience in parenting and who were presume to be watching us instead of abusing us. As a result of my early childhood, I grew up without love and caring. As an adult, I did not have the ability to show love towards my parents, brothers, sisters, or even my own children. I had no parenting skills. The only skills I had came from those authority figures; always ordering me around. Now, there I was yelling at my children, and adopting the awful parenting skills of the abusers. Now my children are feeling angry from the side effects of the IRS system.

In our afternoon class, we would go up one by one and tell our stories, recite poems and riddles. Many kids were strapped for not knowing what they were saying. In the schoolyard older kids would tell us what to recite, not understanding what was bad about it, if anything at all. One day I recited a poem called, The Men Who Went To War;

$$
\begin{aligned}
& \text { In the year } 1944 \\
& \text { the men went to war } \\
& \text { They had no guns } \\
& \text { they used their bums }
\end{aligned}
$$

After my poetic sharing, I was sent to the main office on the second floor and strapped by Father Maurice until I cried. There was no such thing as forgiveness, no respect, no consideration, just strap, strap, strap. Force and fear were the tactics used on little children everywhere in the building.

A few decades later I am working with my daughter Wonda. I'm teaching Native Language \& Culture to the little children at the Niwasa Head Start Program in Hamilton. Wonda is one of the ECE teachers. At times, I have heard teachers, guest teachers and staff of the program speak to the children saying, "On your bum, sit on your bum please." It is hard for me to believe that after fifty years, I'm still triggered with these words, and affected by bad memories of being hit and strapped. If only they knew what happened to us when the word "bum" was mentioned in the Indian Residential School. Would they believe me? All of the teachers I work with weren't even born yet, it was so long ago. My little friends at Niwasa (little ones) always made my day. In our little circle they would pass around a talking stone taking turns sharing stories of their little escapades. From the spirit stone they have learned how to listen and respect the person speaking. 
One of the Seven Grandfather teachings is Mnaadenmowin or, in English respect. This is always the message given to my little friends at Niwasa Head Start Program. I feel so good to share such an important part of our culture with the little children. There is no such thing as abuse in our Niwasa building. Shaming in front of others can be devastating to a Native child, any child, and is not something I have seen happening there.

Our cultural belief has always been that children are gifts from the Creator. Etched in my mind is another cold winter morning at IRS. I may have been 9 years old, and we unexpectedly had a fire drill. It was still dark when the fire alarm went off. There was a lot of commotion, running and bumping. I remember that I slid down a cold pipe to escape from the third floor to the second floor level and onto the ground. There was a little boy, Ivan, he limped when he walked. He was coming behind me crying very loud, and somehow he lost his footing and fell on top of my head. I may have been knocked out for a few seconds. My body acted as a cushion when he fell on top of me. When I came to, there was a crowd around little Ivan trying to ease his pain. Some kids were crying from the freezing cold, and some kids had no shoes on. We had on white cotton gowns that looked like dresses symbolizing little white angels. Finally, Ivan was taken to the Infirmary. Explaining the accident the way I wanted to would have done more damage. I had been strapped much too often for speaking my language and speaking when not spoken too. Gradually, I was learning the no-talk rule, and internalizing an inability to make a complaint. I was taught to fear authority and taught to be silent. This teaching has hurt me all my life, and I used a fist or alcohol to draw attention to what I thought I wanted. My Grandmother was in Residential school as a child, and so was I. Now, my children, who did not go to IRS, also feel the effects of what has come to be called the Indian Residential School Syndrome.

I remember coming home on one of our summer holidays from the school; I may have been nine years old. My brother Eugene and I were playing on a wooden swing gate by the road when our neighbor, a little boy named Jimmy Joe, made an effort to play with us. He went running back up the hill yelling in Odawa "Mama, mama, Gordon is talking funny!" I guess he was frightened, because Eugene and I must have sounded like turkeys to him. It was English coming out of us like we had been born speaking it.

We lived in one of seven satellite areas in Wikwemikong Reserve. Several kids arrived from Spanish Residential School to live and help on the farms. Separation amongst them was usual. Many kids were from different reserves, some with different dialects. One of those kids lived at the Enosse farm down hill from us. He was my friend Stanley Johnson, and was originally from Bkejwanong Reserve. Stan couldn't speak Native. He's an example of someone who once spoke his language, but could no longer speak it, because of the domination he received at school. He would drop by to visit and we would always talk in English. One day my father got after Eugene and me. He said, "Stop talking English around here. What is wrong with you?" Speaking English was a force of habit, and the fact that I kept forgetting that my mother only spoke the sacred language was not very respectful on my part. How was I supposed to know? I was only a kid. I never forgot one of Stanley's comments. He said to me, "Gee, you got it bad. You can't speak Native in the School, and you can't speak English at home. We both laughed. He was right thought; I couldn't win either way. Stan died when he was 59 years old and he never fully recovered his stolen language. It is good to know that his funeral was in the Traditional form; something crucial to our Native custom.

This is only one important example of what our people went through and are still going through today. Our language is essential to the maintenance of our culture. Facts and information can be stated in any language, but the beliefs, feelings, and way of looking at the world through the eyes of a culture are lost when translated in to another language. The words and structure of a language express the feelings of a people and their culture. Words that are supposed to be parallel in another language do not fully and accurately portray those feelings. Therefore, changing to a different language results in a loss of a part of our culture. The loss of a language also leads to a breakdown in communication between children and their grandparents, sometimes even their parents, and denies children their heritage. Forcing Native children to suddenly give up their language, and speak only English, like we were in Residential school, reinforced the idea prevalent in many of the schools that the Native language and culture are of little or no value, thus effectively destroying the self-concept of many students.

It's funny how one always remembers where they were when something drastic happens. It was in 1954, and I was in the Indian Residential School in Spanish Ontario. We were in Church when the priest announced, "Wikwemikong church burned down." It must have been a sad time for the people back home to see the symbol of their beliefs collapse. I don't remember ever being in that church, but my mother told me I was baptized in it. I clearly remember the priest at the IRS announcing, "There will not be any more drum play in the school grounds. Drumbeats, yelling and chanting is a sign of devil worshippers. This he proclaimed in the church, a place of worship. Many of us kids would play 'Cowboys and Indians' after watching the movies and we would bring into play an old beaten galvanized pail for a drum. We lost our Church at home, and our feeling were not acknowledged, and at the IRS Church we were told what to do and what we could believe and that 
our own beliefs were from the devil. There were many drastic events in our young lives.

Our Ancestors practiced laughter, yelling, talking, and crying as gifts of healing. Dancing yelling and singing is a spiritual process deeply embedded in the historic use of the drum. The early 'Black Robes' could not have understood this in their struggle to convert the Native People. Subsequent events at IRS showed us that the Priests panicked when they saw us children playing out cultural activities. Years later in the fall of 1998 on a chilly evening I went to a gathering at Spanish Residential School with Don and Henry Jocko and Joe Bonaparte from Akwesasne Reserve. They were also survivors of the Spanish School. The Residential School had been condemned, except for the church section where the gathering took place. We all sat in a sizeable circle. I felt very uncomfortable, agitated, cold, and I was completely disassociated from my sense of self. This was because long ago in this huge building, time and time again I had experienced an atmosphere of fear and dread of the unexpected. Unwelcome memories were coming back at me, and finally the meeting began with the entrance of the sacred drum. Only then did I feel a sense of strength, and find myself again. I was so proud to see the spirit drum come back to where it had once been mocked and eradicated. That night a number of people slept in the church section of the building. I couldn't sleep there. I had slept in that huge building too long. A sudden fear of more recollections became too disturbing, and nothing could stop me. I went home. But, I learned from the silent messages in my head, that boyhood trauma could play hell with a man's memory.

One Easter Sunday my Mother and Father came to visit. A neighbor drove them 100 miles to visit us, but they could stay for only a short time. Rules had to be followed. My father gave Francis $\$ 10.00$ dollars to divide between the three of us. As a rule Francis in turn had to give the money to Father Maurice, who was entrusted with the care and spending of funds. I remember I made three trips to the main office to collect a quarter each visit so I could by goodies at the canteen shop. Twenty-Five cents provided me with a chocolate bar, soda pop and few candies. On my $4^{\text {th }}$ visit, I was told I had two other brothers and there was no money left. I told my brother Francis about the situation. He explained to me he also made 3 trips to the main office getting a quarter each visit and was told the same thing, likewise my brother Eugene, so $\$ 7.75$ was kept back from us. This was a system that never stopped taking; nothing was ever mentioned again about this criminal act till we got older. That experience taught me how close crime and authority work. It seems to work hand in hand, the law and the outlaw.

In 1969, I came home to Wikwemikong from Detroit for the Christmas holidays. My brother Francis and I decided to take a drive to the south side of Wikwemikong known as Deweganing or South Bay. We stopped at one log cabin, where we met two friends, Clarence Petawanakwat and Joe Louise Lavelley. We all went to school at the Indian Residential School at Spanish. We talked about the humorous occurrences we went through at the IRS and the hockey players we idolized during that time. We talked about the guys we knew by their numbers and the intimidating and funny nicknames they were given and the ugly nicknames we were called. We reminisced and joked about the things we remembered at the IRS and we had a good time. Now I understand that we were avoiding the atrocious crime that had been done to us as children. We were laughing, not because it was amusing, but because there was a lot of pain. Reminiscing in a humorous way about our past experiences was our way of coping or adapting to our present situations. Clearly for most of us, the reminiscing experience continues to be painful. We had to ease the pain somehow, and we did by laughing. Two of my relations, Bezhniik and Maaniiyaanh from the community, came in while we where talking about our experiences. Joining in our conversation, Bezhniik mentioned how she had learned how to hem, mend, and sew in the Residential School. She claimed that if she didn't attend there she wouldn't have known how to sew. This was hard to believe because Native women are most excellent in weaving stitches, dress- making and beadwork. They were doing embroidery work before darning needles were ever brought into the country. Maaniiyaanh then stated that if she didn't go to IRS she wouldn't be speaking English today. It is sad to know that today Maaniiyaanh's grandchildren can't speak their Native language. Girl's school may have been a little leaner than the boy's school when it came to painful experiences, but abuse is abuse. Half of that day went by very quickly as we talked and joked. It was certainly stimulating using humor to get past trauma.

This still happens today whenever my brothers and sisters from all across Turtle Island talk about their residential school experiences. We use humor, but underneath all that laughter, there is a deep sadness and there are some really sad cases. We learned to maintain strict composure during beatings, live out fantasies about present and future circumstances in our minds and in total silence, and we idolized those who ran away from school. Some refer to the Residential School their home, but I know from that forced childhood home, we brought back to our family homes "issues." The issues we are dealing with today as a result of being taken away from our "real" homes have created a lot of hurt. The survivors who practiced detachment effectively distanced themselves from the source of hurt, whether by "shutting down," not speaking or hearing, or joking and laughing about the source of their pain. Others reinterpreted negative situations in positive way like Bezhniik and Maaniiyaanh. 


\section{Zhaawonde - Dawn of a New Day}

The St. Charles Garnier Residential School was demolished, but it was not a pretty site to begin with. In its place, a huge Monument now sits as a reminder. It gives the entire picture meaning; then and now, past and present, a child and an adult. It is good to have the new monument in place where the school once stood. It tells the truth. The Residential School survivors will not be with us forever, but the legacy of their survival must live on, and never be forgotten.

My father had given me a Potawatomie name, Zhaawondenhs. But when it came time for me to learn the English language at the Residential School, my name was thrown out as heathenish rubbish. Consequently, a new name came about. One day I was out of the boundary line, pocketing fruit under the apple tree. The Prefect Father Orr said that I was out of bounds and running away. I was immediately sent to the second floor of the school. I was crying, frightened and thinking I was going to have my head shaved. Hair cutting and hair shaving was common punishment for a run-away and it was always done at the Barber Shop on the second floor. I was rescued by my friend Henry Jocko, he was the Native student barber that day, and he tried to make me as comfortable as possible, but my weird haircut was still bad. Father Brennan came into the barbershop and in a demoralizing voice said "hello Flat Top." From that day forward the name-calling began to no-end. I was known as "Flat Top" in the Residential School and at the Wikwemikong Reserve. I hated that name. It was powerful how much that name affected my mind. That name took me from the innocence of picking fruit to a sudden meeting of 'dread and fright', and that fright stayed with me throughout my lifetime. The simple act of feeding myself apples represented a challenge to the authority of that priest, more importantly, it was proof that the black-robes possessed the necessary strength to comfort and persecute a student and win, and that they the ability to bring him down to the lowest level.

When I got married in 1965 I came home and was startled to learn that it was Father Brennan who was to perform the wedding in the village. When I came up to meet him, he said "Why hello Flat Top, long time no-see." I felt humiliated by the name he called me in front of my fiancée, and I sensed that nothing had changed. The same force they used at the IRS was noticeable in the black robe that monitored a few activities in the Wikwemikong village. The name Father Brennan gave me in the Residential School was an expression of his power, it was offensive, and represented intimidation and abusiveness. This name is still used today towards me by a handful of people who don't know what they are saying and where it came from. It was something I came to grips with somewhat accidentally, but it was necessary to end my continuing to be afflicted by it.
This is how it happened, one day I was on the school grounds in Wikwemikong. About a block from the Pontiac School Reserve school is a restaurant called the Odawa Inn. It is a popular place for students to gather at lunch hour. Inside are simple unadorned tables and comfortable chairs. It's unpretentious and cozy. I took a walk there at noon hour for some pop and chips. My friends Dave Mishibinijima, Harvey Wassegijig, Tony Shawana and Harvey Bell saw me approaching. As I walked in the place, I could see that the place was packed with teenagers. Dave deposited a quarter into the Juke Box and said we got a song for you Gordon; as it comes on they're all smiles and I'm wondering what it could be. It was a song by Johnny Cash, 'The Tennessee Flat Top Box.'Anything for a laugh with Flat Top in it I guessed, but I realized that my nick-name mentioned in the song reminded them of me and for me it was kind of an uplifting feeling. It took on a new sense, a "feelingrealization, enlightenment" kind of response, and this time I took no offense. The song was a big hit in the country music field and here were these crazy friends of mine clapping their hands and loving it and all of a sudden I realize I'm all for it, and feeling no pain. From then on, every time I heard that song, it made me feel special. I have to thank those boys for the clarification, clearing up the irritating feelings around the Flat Top nickname, and the memory for how it came about. These friends of mine have since gone on into the Spirit World, but I will never forget them. The song they played will always be inspirational source to me, and yes, the history of Flat Top will live on.

Another source of insult came from the Jesuits finding a way for us to escape boredom for an hour or two by watching the popular cowboy and Indian film nonsense. The films taught us that the white man was the good guy and the savage Indian was always the bad guy. When we played outdoors and imitated the actors everybody wanted to be a cowboy and nobody wanted to be an Indian. The Indians massacred people, if not the innocent settlers, it was those passing through on wagon trains. It was something we were obliged to watch and eventually took for granted. We didn't understand that the settlers stole Indian lands. This movie nonsense contributed to my shame of being an Indian (identity $=$ language). I grew up not speaking Ojibwe at school, or to my children once I had my own family.

In the Aboriginal Spirituality course, through which I participated, at the University of Toronto, I learned that "no native can grow to any age without being informed that her/ his people were 'savages' and that they had interfered with the march of progress pursed by respectable, loving civilized whites" (Lee, 1959). We were villains of each of the scenario's we were shown in those old movies, and when we were mentioned at all in books, we were absent from much of the progress of 
white history except when we were and are calmly, rationally, succinctly, and systematically dehumanized.

In September of 2003, I had the privilege to teach Ojibwe, "examining the morphology of words" at McMaster University in Hamilton under my colleague Mr. Isadore Bebamikawe (Toulouse). The students consisted of those learning to be linguists, and people going into Social Work and Anthropology. These were people who would eventually deal with the physical, cultural, and social development of man, including his origin and behavior. I found it interesting on more one occasion. As my awareness grew, I became lost in thought over my quick first impression at seeing all these people sitting in front of me. I was thinking, "Who stole my talk? Who stole my way of thinking? Why am I teaching Ojibwe to the white man?" I was increasingly conscious that this kind of thinking came from a loss of a normal lifestyle, and from a lack of trust caused by attending Indian Residential School. I can forgive, but it doesn't mean I can forget.

More recently, I have read about Dorothy Lee, an anthropologist interested in how people from different cultures perceive their immediate environment, described what she saw while looking at trees outside her window. "I see trees, some of which I like to be there, and some of which I intend to cut down to keep them from encroaching further upon the small clearing I made for my house" (Lee, 1959). In the same passage, she contrast with her perceptions of Black Elk, a Dakota Native who saw trees as having rights to the land, equal to his own ..."standing people, in whom the winged ones built their lodges and reared their families" (cited in Lee, 1959: 1). For First Nations people, everything comes from the Anishinaabemowin (native language). It's how we talk, how we walk, and how we think.

In our sacred ceremonies a two-spirited person is thought of as a special person. It is considered a gift to have two-spirits in one body; it is a great honor. Many two-spirited women of the past were warriors and political leaders and many women are those things today, just in different ways. Women warrior today fight against injustice and poverty. Those who are politically minded may become lawyers and join various levels of government, both on reserve and off. The first Europeans had no tolerance for a flexible, Indigenous concept of sexuality and gender. The presence of openly accepted homosexuality went against their deeply held religious beliefs, and gays and lesbians, as well as traditional spiritual leaders and women, were devalued by patriarchal Europeans because of the power and status they held within their Aboriginal communities. Colonization means the loss not only of language and the power of self-government but also of ritual status of all women and those males labeled 'deviant' by the white Christian colonizers". As a result of Christian colonization, the long-held traditions respecting the special gifts of gays and lesbians, as well as their important ceremonial roles, were largely forgotten. Under the Christian Church led Indian Residential School System, Aboriginal children were taught to feel ashamed of their culture, as well as guilt and shame about their bodies and sexuality. For many children, this shame was compounded by the trauma of physical and sexual abuse. The impacts of shame and unresolved trauma are seen today in the reluctance of Aboriginal people to speak openly about issues of sexuality and sexual orientation, leading, in turn, to greater isolation and shame.

Four of my siblings were in the Indian Residential School System, Doris, Raymond, Francis and Eugene. Many of Aboriginal people left the residential school as misguided people and countless died at an early age. Many searched in the wrong places for self-respect and identity and many found self-destructive ways to cope with the outside world. My oldest brother Ray died of exposure from alcohol-related causes. My brother Eugene died by taking his own life along with the bitter memories rooted in experiences Vietnam War. My other brother, Francis, died from what has come to be known as the "legacy disease," the same old blame; Cancer. I thank the Creator for their loan.

Going back to the reserve was not easy, even though it was nice to be home. At the village schoolyard we were known as bad kids, the kids from the institution. I started fighting the other kids because I was angry. All my family values were broken and destroyed in the IRS and now in my community. The traditional ceremonies and medicines disappeared, and our health and cultural/language was in limbo. I had been abused in the IRS and I had a lot of abusive behaviors like anger, rage, impatience, and yelling that I brought home and applied to others. I was violent often; even directing my anger towards my mother. I had become a hyper kid with a troubled spirit. I showed a lot of forcefulness, and got into a lot of arguments and fights. I was an angry boy filled with fear, and fighting was the only way to get rid of the fear. The signs of great inner pain that branded me felt like it was locked within forever. We hold our anger in our bodies, storing it within the organs and tissues. This coping method of repressing anger can lead to illness, disease and eventually death. My brother died of cancer, my brother repressed his feeling too; many of our people died this way.

After the closing of the IRS at Spanish Ontario in 1958, some of the Jesuits went on to work on the Reserves where they became well known and respected. I know the desire to belong and be accepted is an essential human need, but I will not, cannot deny what happened to me and what I experienced in the Indian Residential School during my childhood. The 


\section{Zhaawonde - Dawn of a New Day}

Jesuits Priest had a job to do. Likewise, I now have work to do. I understand that healing is a life long journey.

As the years have gone by I have begun to catch a glimmer of what I missed those many years ago. I am immersed in learning about aboriginal spiritually, and learning phrases like, 'sustainable development' and the 'harmony of all living things.' Our Aboriginal cultures are still rich with ceremonies designed to build strength, restore balance and promote healing. Traditional teachings have always included behavior modification, cognitive therapy, and narrative therapy. Our children learn through the stories of the Elders, making connections from the stories to their own life journeys. I began to see more clearly what my Ancestors meant when they said their life was linked to the land. From teachings, we learn to respect and preserve the earth that gives us life. The courage of aboriginal survivors to heal themselves their families and their communities is a source of inspiration. They are living embodiments of the strength, beauty, and resilience of the First Nations People, Inuit, and Métis. They are transforming the pain of their past into hope for a new future.

I left the Reserve at an early age not really knowing my own spiritually well enough to comfort me, but I always felt something was missing. That something was what only my Ancestors could give. I felt isolated, and left home like an undisclosed top-secret package, on the road to a nowhere life. My road ended up being a long, lost tale of confused wanderings and loneliness. It was an experience of city lights, fast living, marrying early, divorcing early and ending up in endless taverns. There were too many years of late night parties, after hour hangouts (bootleggers), fist-cuffs, and never holding onto a job longer than 3 years. Eventually, I turned into an alcoholic, never realizing that I was heading for catastrophe.

Temp Offices were everywhere in USA in the 60s and 70s. No one could ever get stranded anywhere if they wanted to work at temporary jobs. It was good for traveling and staying alive. Temporary work became my specialty. Traveling and living in the Slums of Houston, New Orleans, Buffalo and Syracuse N.Y. and then back to Detroit. Finally, exhausted and stuck between two worlds, I had plenty of work to do on my self. At the age of 45, I had to face and relive my childhood years. I had to go back, and then further back again, to my earliest childhood to find that point of transition and learn how to feel proper.

Today, I feel proud and gratified that I found my Spirituality, that I found my heart, and that I am able to walk the red road with my own people and the Spirits of My Ancestors. I feel like a warrior that helps others who are not able to speak-up for themselves. Many of my thanks go to the Native Horizons Treatment Center, the Rain Dance Society, Susan Aaron's Psychodramatic Bodywork Training in Toronto, Cindy Baskin's Traditional Counseling, and Dr. A.A. Dunlop who is associated with The Canadian Native Center in Toronto. I can also thank Ontario Health Canada and the many Native writers with their brutal honesty, the amazing Naandwedidaa (healing one another) program in Wikwemikong, and all of the Care-Givers that have supported me on my journey to healing and releasing of painful memories.

\section{End of Part Two}

\section{Living in the Now...}

I keep myself busy today. I look for interesting things to do. My hobby is collecting classic movie videos. Through out my boy-hood days, movies always helped me to break away from reality for an hour or so. I find watching motion pictures a great way to entertain me at home, and I can always turn to my video movies for comfort. They're filled with glamour, romance, excitement, and escape and I get a sense of what it must have been like back then in better places than where I was. The world isn't all bad.

I collect videos at yard sales; flee markets, and antique fairs. It's a hobby that keeps me going because of the running around and looking for them. I get a lot out of the traveling to distant places to find them, trading, doing research, and the sharing with people with similar interest, and the joy of finding good ones. It carries me, and I have no time to think of my pain or illness, and therefore these movie treasures and memories become more precious as time goes by.

The movies that interest me the most represent different cultural expression. They are inspiring and educational. Westerns movies (cowboys and Indians) give an idea, although sometimes wrong, about an important time in American History. Aboriginal people have beat incredible odds in their struggle for freedom. They seem to have a tremendous sense of spirit and express good feelings of reality, especially as that history becomes clearer. When I'm looking for laughs and love, I'll reach for and grab a movie of show business biographies, and watch public triumphs, private failures, career declines and fantastic comebacks. These wonderfully exciting musicals and words put into images what a person feels in his heart. Included in my collection are silent movies, films of the twenties, and thirties, film noir, the fabulous fifties, biographies and Walt Disney's greatest creation Mickey Mouse. All are highly pleasing to me. Buying videos in the market place has come to an end, and finding classic video movies has become more challenging for the serious collector. Many movies have never been released for TV, Video or DVD and are lost to public. For me, preserving classic movies has become a way of preserving history.

My life has change considerably over the years. I don't have a big income, just enough to keep me alive. However, I don't miss money because I began my life without money. I 
keep my eyes peeled for saving advertisements and thanks to the Shoppers Optimum card, the more I shop the more I earn points, and the more I save. I have never shopped like this before, but at least it keeps things interesting. I don't own a car, and therefore I don't have to pay for auto insurance or for parking. I don't drink alcohol and I don't smoke cigarettes, and if I did there are already plenty of good reasons to butt out!

There are other interesting things to do in this world. I do volunteer work, and I am a member of the Board of Directors at the Akwa Honsta a non-profit housing company. All of the directors volunteer their time to be on the board. The mandate of Akwa Honsta is to provide safe clean and affordable housing to individuals and families. They have a specific mandate to provide rent-geared to income rental housing in the Aboriginal community of Toronto.

I also take pleasure in doing volunteer work at the University of Toronto, sharing my story in class about my experience as a young boy in the wilderness and at the Residential School. The University students better understand what the Residential School was like from the eyes of a Native Child and my stories of the past raise awareness of Aboriginal culture and history. They are helping to write my story using their writing skills and their knowledge of correspondence and the academic literature. They have been tasked by their Professor, Cynthia Wesley-Esquimaux to match their writing as closely to what I say as possible. My story will have more truth when I tell it the way it was directly from my memory and my life. Now they know that for too long our stories have been silenced, and they are willing to help people like me bring them to life.

Some of the things I do, I find are a little difficult now. Staying in condition is not easy, but I go for long walks, do sit ups, and finding the right combination of food is good for my stomach. I make sure I get enough sleep. Sometimes, I'll wake up in the middle of the night and if something comes to my mind, I'll start writing. I write for pleasure, and I am finding that writing can be a form of healing; an active mind is always a healthier mind.

I have a better appreciation for the beauty around me now, and I enjoy listening to many different types of music from the past and by musicians gone by, like the jazz bands of Duke Ellington and Benny Goodman and stars like Frank Sinatra, Doris Day, and Elvis. They are gone, but they will continue to shine for me. I try to understand the Rap music that young people listen to. If the group is expressing their feelings and voicing their concerns more power to them. My favorite Country Artist is Crystal Shawanda, Wikwemikong's own ambassador to Opry Land. I have a daughter named Crystal Shawanda as well and I love her dearly. Obviously, the three of us have never met our great, great Grandfather Zhaawonde, but his name will continue to be heard and it will shine in Crystal's songs under the bright lights of The Grand Ole Opry.

I'm thankful I have a friend back home that I have kept in touch with throughout all the years. Robert Takwadjiwan and I grew up in Wikwemikong, and we worked in Detroit many years back as well. Once in a while our old drinking days will pop up in our conversation, but we don't dwell on them. Of all the things I miss is there's nothing more pleasurable for me when speaking Ojibwe to my friend Rob. There are always laughs when we speak our own language, our gift from the Creator. English is not the same; words do not carry the same representation they have in the Ojibwe language. This is one reason I enjoy my phone conversations with him and speaking in our Native Tongue. I miss the clean expression and amusement that comes with laughs and admiration in the language of our Ancestors.

Some of my children and my Grandchildren live in another city not far from me.

I feel it's my duty to help and guide them. I'm partly responsible for why they live in the city. Like other families we went through some hard times with racism, alcoholism, drugs and death. Sometimes, seeing some of my grandchildren living in apartment buildings has a negative affect on me. I feel I should be on the Reserve with them where there is clean fresh air and room to grow. Living in the city may be tough for some of us, but we cannot let the Dark Cities frighten us. Once we truly understand about the Earth we walk on, an Aboriginal person can survive anywhere on Turtle Island. To "survive" in North America is the gift we alone were given to use by the Great Spirit. It's our home and our neighbors came later. I will continue to do my best to guide my grandchildren, and great grandchildren. Our teachings stand tall everywhere and I will never again be lost in this Country. In my heart I will always have 'Wikwemikong Mnidoo Mnissing Land of the Spirits' alive and remembered in a good way.

\section{End of Part Three}

\section{Keeping the Spirit Alive}

It was a beautiful afternoon in 1996 and my first year dancing at this ceremony. In the community of Wikwemikong Mnidoo Mnissing the dance I was doing is called the Rain Dance Ceremony. People came from distant places seeking spiritual strength. They remain inspired by their past and here everything lives. Family, medicines, plant life, animal life, and the sky-spirits, surround them. It is a land full of meaning and mysteriousness, where our Ancestors taught us that Native land goes hand in hand with the Native culture and traditions. 


\section{Zhaawonde - Dawn of a New Day}

The Saulteaux (Soo-Too) are here from Saskatchewan to participate in the Rain Dance ceremony and they bring with them the Buffalo Spirit. This is a 4-day event, beginning with the building of a Medicine Wheel, and the sacred lodge. Number 4 is very symbolic in Native Culture, and many things are expressed in sets of four. Therefore, this number has always had special significance in our way of life. In the center stands the tall Sacred Tree surrounded by the four Grandfathers, Waabnong, Zhaawnong, Epnigishmog, and Giiwednong. The doorway faces Waabnong. Everyone attending the ceremony volunteers to help wherever help is needed. No time clock is needed because whatever is to be done in these 4-days will be done. This is the place of re-learning our way of life and feeling the Spirits of our Ancestors. People come year after year and learn new things as they listen and participate. They learn by listening carefully to the songs and words or just by watching the proceedings. It is about understanding the Medicine Wheel of life, through which we learn, grow and change by allowing each person, place, object or experience to teach us. The Medicine Wheel helps us expand our ways.

The drummers offer a prayer by singing, and the dancers begin to dance. Immediately, I notice that next to me is a 12 year old boy who is going to participate in the fasting, dancing, and blowing of the eagle cry (whistle) for 4-days in the heat or rain. The boy tells me his name is Zhoolyea. One could tell he's been around the teachings; he's very bright, helpful, and very energetic. On the second day I was starting to move slower, but Zhoolyea seemed to be moving faster. I thought I was imagining things but he really was full of life. I was having a hard time trying to concentrate, my rubberneck was moving here, there and everywhere. In the late afternoon on the second day noticing my actions, Zhoolyea whispers "come here for second." I bent over beneath his nest (stall), and he tells me "you need to stare at the sacred tree." I said in return, "the clowns distract me," but he says "there are no clowns out there. You have to keep your eyes on the sacred tree, and treat the ceremony with respect." Zhoolyea kept speaking, "The Elders tell us, give the sacred tree what it needs from you, respect.' Show all your feelings, your suffering, and your need to cry. The tree of life will help you and it will give back for your suffering. The sacred tree is giving you a test of physical and spiritual power and when the Rain Dance is over, you will feel the strength and cheerfulness. Just try it, always stare at the tree and pray hard." I thanked Zhoolyea for his teachings, and I made the fourth day drained with sweat and completely exhausted.

Here was a 12 year old telling me something I didn't know, something that I went on to do and value. In the early Sunday morning on the $4^{\text {th }}$ and the last day, the Thunder beings had brought power and their presence was felt everywhere. They are a symbol of protection and guidance. Spirit wind and Rain remind us that one must honor the Great Spirit and his work in Nature. It is an honor to be part of the Great Mystery and to be a part of performing and guarding the ceremonies. The Rain dance encourages positive growth in all areas of life. The Medicine man Epnigishmog is there for our help, he is present as a very wise man and he's our guide and mentor during the four days.

I watched a 4-year old boy drumming happily with his Father. The kids start learning the lessons of the drum early. The holder of the Sacred Drum teaches and makes sure that no one will ever contaminate, handle or come near the Spirit Drum, when they are involved with substance abuse whether it is alcohol or drugs. The call of the drum brings powwows all year round to North America, and the circuit has expanded as pride in Native culture has flourished over the last fifty years. Mothers carry babies in their womb for 9 months and when the baby hears the mother's heartbeat they react with comfort. When little babies follow their mothers to practice drum, to ceremonies, and to powwows the sound of the Drum soothingly puts them to sleep. The beat of the drum represents the heartbeat of Mother Earth, and their mothers, and newborns and toddlers know this way of life belongs to them.

Twelve years later I'm at another Rain Dance Ceremony about 400 miles from where I live in Wikwemikong. I have sat in as a Grandfather before. Now, I'm asked if I could find a tree to represent the Tree of Life. It's an honor to be asked. I go on with the proceedings and I find the tree we will use, and I'm hugging the tree, my forehead against the sacred tree praying and crying. I'm apologizing that we have to cut down the tree for a good cause. I offer semaa (sacred tobacco) placing it on the ground for taking its life from Mother Earth. The person that is with me yells out to the people on the sacred grounds four times; we have found the tree. Everybody comes and gathers around the sacred tree. I haven't danced in the eagle's nest for 12 years now, but I will always dance in the lodge with the people who have come for help to pray and dance to the Mishoomis (grandfather) the Sacred Tree.

It is most important to always give tobacco to one of the four Grandfathers sitting in front of the altar, but it is your choice who will pray for you. Traditional tobacco was given to us by the Creator to use so that we can communicate with the spirit world. Tobacco opens the sacred door to allow that communication to take place. When we make an offering of tobacco, we communicate our thoughts and feelings through the tobacco as we pray for our families, others, and ourselves. When you seek the help and advice of an Elder, Healer, or Medicine Person and give your offering of tobacco, they know that a request has been made and they will complete a 
First Peoples Child \& Family Review, Volume 5, Number 1, 2010

ceremony or prayers for you because Tobacco is most Sacred Gift. Tobacco was the Native's gift to the Newcomers on Turtle Island, or what is now known as 'North America' to the world.

On the fourth and final day I had a rather disturbing experience. When the Rain came, people outside the lodge ran under the trees. I kept dancing and praying and staring at the sacred tree as I had been instructed. As the rain came pouring down, I took off my red t-shirt to welcome the rain. It was something I had learned from watching Epnigishmok in Wikwemukong. To welcome the rain with no shirt on is like welcoming a cleansing of your spirit, giving you a new life. As I danced, I heard someone say, "Take your white shirt off" and the second time he said it, people laughed close by him and I recognized his voice. This man is from the woodwind family, he carves flute for a living, and I admire him. I had taken my red t-shirt off and now he saw my fair body color with my brown arms. I laughed, it did sound funny at first. The third time he said it, I knew this man was being a bully and that he wanted attention.

Now, I feel him behind my back laughing and dancing and not realizing what is going on in the Sacred Lodge. I feel that I have my hands tied, but am keeping my eyes on the Sacred Tree in Respect. I kept praying and dancing. I kid myself and try to hang tough and not get angry. I don't want to turn around and stare him right in the eye and give him any satisfaction, but this man is telling me I am different. The people are laughing, not at me, but at him because of the remarks he is making. At least that's what I am thinking and telling myself. I understand however, that those kinds of words produce community lateral violence, bullying, an intentional creation of crisis, and prejudicial discrimination based on race and color. All of which are a direct link to the colonial forces I experienced at Indian Residential School. I am increasingly aware that a part of me has strength and part of me has a weak spot. What happened is this; it was my little (inner) boy who was hurt. It had nothing to do with the man who made those remarks, but eight months later, my little inner child is still feeling the pain. That is how I have become more aware of the ways that the IRS has affected me. I am again a little boy walking in front of jeering boys and a laughing priest carrying a straw mattress to the barn. This is how the Indian Residential School continues to affect me in the Now.

It is good to go and see an Elder, to have someone see a situation through their eyes and heart, more clearly than someone who was involved in it. I needed answers, so I talked to a Medicine Person in order to understand where I was coming from. His belief was both of us were troubled, the man who made fun of my skin and me, but neither of us knew it. That man blamed me for his troubled life, and bullied me to make him feel better, and he doesn't know it. I don't respect him for what he is doing, and it means that in turn, I don't respect myself, and I don't know it. I want the younger generation to know these things and know how to heal them, for each other. This story had to come out of me to make it possible. Our young people must be the ones to take the lead.

\section{End of Part Four}

I want to thank Professor Cynthia Wesley-Esquimaux and the students at the University of Toronto for giving me the opportunity to write this story. They gave me the motivation and encouragement to write. They were behind me 100\% it was like they wanted to learn more, and we loved it. They got me inspired, and they got me working and they provided me the additional wording I needed. They are my friends who now understand where I'm coming from. Chi Miigwech to each one of you, $G Z$ 